\author{
中口国境貿易 \\ ——黒龍江省の対ロシア国境貿易を中心に—— \\ 封安 全 \\ (北海道大学文学研究科博士後期課程)
}

\title{
China-Russian Border Trade Focusing on Heilongjiang Province
}

\author{
Feng, An Quan \\ Graduate School of Letters, Hokkaido University
}

\begin{abstract}
Recent years, Chinese-Russian border trade develops rapidly. This trade is a part of the Chinese-Russian economic and trade cooperation, and it plays a major role in the development of the borderland region of the two countries. There is a general understanding of the meaning of "border trade", but it still has not an exact definition. The information materials concerning this trade have not been analyzed consistently.

In this paper the author clarifies the definition of border trade and its concrete systems, Mutual trade (in Chinese:hu shi mao yi), Small amount trade (in Chinese: bian jing xiao e mao yi), consignment trade and shuttle trade, using the result of interviews and data gathering in the China-Russian borderland region, carried out by the author in the period from July to September 2007. It also examines more closely the dynamics of the borderline trade policy of the two countries. Because the Heilongiang province accounts for more than 60 percent of all Chinese-Russian borderline trade, the paper analyzes the statistical materials of this province and examines main causes for changes in volumes of border trade. It is demonstrated that the border trade has been largely influenced by the policy of the two states and by the .recent economic booms in two countries.
\end{abstract}

$$
\text { は じめに }
$$

近年, 中口間の国境貿易（辺境貿易）が急速に発展している。中口国境貿易は, 中口経済・ 貿易協力の一部になっており，両国の国境地域の発展において大きな役割を果たしている。し かし，この国境貿易の定義や制度については瞹昧な部分が多く，また，ロシア側は，国境貿易 を認めているが，明確な定義や制度は存在しない。さらに，中口国境貿易のデータについて も，これまできちんとした分析がなされてこなかった。

本論文の目的は次の二つである。

Keywords: Chinese-Russian trade, border trade, Heilongiiang Province, shuttle trade 
（1）中口間の国境貿易についての定義や制度を明らかにする。とくに，1990年代初め以降の 中国側の制度の変遷を検討する。中国全体に関する制度だけでなく，中口国境貿易の中で最も 重要な黒龍江省の対ロシア国境貿易の制度についても明らかにする。ロシア側に関しても，中 口間の国境貿易に影響を与えた通関制度等について検討する。

（2）中ロ国境貿易全体および黒龍江省の対ロシア国境貿易の動態を分析し，変動の原因を解明 する。

中口国境貿易についての情報は断片的なものが多く，本稿で利用できるものは限られてい る。このため, 本稿では筆者が 2007 年 $7 \sim 9$ 月に行った中口国境地域（綏芬河, 東寧, ウス リースク, ウラジオストク）に打ける聞き取り調査や資料収集の成果を活用している。

\section{1 中国における国境貿易に関する政策}

中国と隣接する国は, 北朝鮮, ロシア, モンゴル, カザフスタン, タジキスタン, クルグズ スタン, パキスタン, インド, ブータン，ネパール，ミャンマー，ラオス，ベトナムなどであ る。これら全ての諸国との国境地域に扣いて国境貿易が存在している。中国が改革開放政策を 実行した 1978 年以降, 東南沿海地域の経済は急速に発展していったが, 内陸及び沿辺（国境 地方）の経済は立ち遅れた。80 年代半ば以降，政府は国境地域の経済を発展させるために， 対外貿易に関して以下のよらな 4 つの優遇政策を打ち出した。

（1）1984 年 12 月 20 日，中国国務院は「国境小額貿易に関する臨時管理弁法」を公布した（『中 国対外経済貿易年鑑』1985，p. 75）。この弁法において，国境小額貿易は，国境省・自治区人 民政府に指定された国境都市・町と隣国の国境都市・町の間の小額貿易および両国の国境市民 の間の互市貿易を指すとされた。国境小額貿易は省・自治区政府によって管理される。国境小 額貿易は次の五つの原則に基づいて行われる。即ち a. 商品の供給源を自分で探す， b. 商品 の販路を自分で探す，c. 交渉（談判）を自分で行う。d. 輸出入商品種類を自分で決める。e. 自分で損益（責任）を負らといらことである。国境小額貿易においては通常の貿易と同様に税 金が徵収される（上掲『中国対外経済貿易年鑑』）。

この政策の背景には次の事情があった。1985 年以前には, 国境地域の貿易会社と企業は対 外貿易権を持っていなかった。この政策によって，中央政府は国境貿易権を地方に与えて，指 定された国境貿易会社が直接外国との貿易に従事できるよらになったのである。

（2）1991 年 4 月 19 日，中国国務院は「国境貿易と国境経済協力を積極的に発展させ，国境の 繁栄安定を促進することに関する意見の通知」を公布した（『商務政策選編』2006， p. 25）。こ の通知により，a．1995 年末まで中国対外経済貿易合作部（現在の商務部）が認可した国境貿 易会社は, 指定される通関ポイントを通じて商品を輸入する場合, 輸入関税と輸入付加価値税 が半額とされる。ただし，この政策は，次の場合，適用されない。

・国家によって規制された機械・電気製品, タバコ, 酒, 化粧品などの商品が輸入される場 合。

・対外貿易権を持たない企業が国境貿易会社に委託輸入する場合。

・輸入された商品が国境地域の省・自治区以外の地域で販売される場合。

b. 国境地区居住民が互市貿易で輸入する商品は, 1 人 1 日 300 元以内であれば, 輸入関税と 輸入付加価值税が免除される。300 元を超える場合は，超過分につき法に基づき徵収される。 
封安 全

（3）1996年 3 月 1 日付「国務院による国境貿易に関する通知」により，国境貿易は国境小額貿 易と国境互市貿易の 2 種の形式に分けられた（『中国対外経済貿易年鑑』1997/1998，p. 111)。

a. 国境互市貿易

国境互市貿易とは，指定する国境地区における陸上国境から $20 \mathrm{~km}$ 以内の居住民が，政府が 認可した開放地域あるいは指定市場において，規定範囲内の金額あるいは数量の商品を輸出入 する活動のことである。

国境地区居住民が互市貿易で輸入する商品は，1 1 日 1000 元以内であれば，輸入関税と 輸入付加価值税が免除される。1000 元を超える場合は，超過分につき法に基づき徵収される。

国境互市貿易を行らためには次の四つの条件に符合しなければならない。

・互市貿易区は陸路・河川の国境線付近に設けること。

・互市貿易区は省・自治区人民政府の認定を得ること。

・互市貿易区は明確な境界線を有すること。

・互市貿易区には税関の要求に符合する監督設備を設置すること。

b. 国境小額貿易

国境小額貿易とは，陸地国境に沿って国が定めた対外開放県あるいは旗，市管轄区（以下国 境地区と略称）に打いて，認可された企業が，国の指定する通関地を経由して，隣接する国の 国境地域企業あるいはその他の貿易機関と貿易活動を行らものである。国境地域における互市 貿易を除いて，その他の貿易方式は今後すべて国境小額貿易の管理に組み入れ，国境小額貿易 についての政策が実行される。

国境小額貿易企業が，指定通関地を経由し，隣国原産の商品（酒・タバコ・化粧品と国の定 めるその他の商品を除く）を輸入する場合は，「第 9 次 5 年計画」前半 3 年（1996-1998 年） に限り, 輸入関税と輸入付加価値税が半額とされる。

（4）1998 年の対外経済貿易合作部第 884 号「国境貿易の発展に関する補充通知」によって国境 互市貿易の免税額が扗大された（『中国対外経済貿易統計年鑑』1999/2000，p. 114）。国境居住 民は，国境互市貿易を通じて輸入商品額が，1 1 1 1 日 3000 元以内であれば，輸入関税と輸入 付加価値税が免除される。3000元を超える場合は，超過分につき法に基づき徵収される。 2000 年末をで国境小額貿易の輸入関税と輸入付加価値税を半額徵収する政策を継続して実施 するとされた (1)。

以上の 4つの政策から分かるように，1996 年以前は，国境貿易の定義や範囲が明確に規定 されていなかった。国境貿易は国境地域において行われる貿易活動であり，実際には，この時 期に国境貿易に従事する会社は，国境バータ一貿易専門会社，地方貿易会社，工業貿易会社， 省外駐在機構（国境地域外の省の企業や会社が国境地域にオフィスを設けるものである）など と広がりをみせていた。対外貿易権がない企業でも，貿易権のある会社を通じて国境貿易を展 開することができた。

1996 年 3 月 1 日付「国務院による国境貿易に関する通知」により国境貿易の定義や範囲な ぞが明確にされた。1996 年以前の国境貿易も互市貿易と国境小額貿易に分けられていたが， それらの定義がより狭く定められたのである。国境貿易に従事する会社は全て国境都市で登録 した会社である。

(1) 実際には，この政策は，2001 年以降も継続されている。 
なお，現在，中国海関統計には，国境小額貿易が記録され，互市貿易については統計が取ら れていない。

\section{2 口シアにおける国境貿易に関する政策}

ロシアでは国境貿易についてあまり言われないが，旧ソ連極東地域と中国の黒龍江省，内モ ンゴル自治区の間の国境貿易が 80 年代から行われていた。1995 年 10 月 13 日付ロシア連邦法 第 No157 号「国家対外貿易活動の調整」の第 22 章 (Собрание законодательства РФ, 1995, о. 42 ,crp. 3923）と 2003 年 12 月 8 日付ロシア連邦法第 164 号「国家対外貿易活動の調整」の第 42 章のなかで国境貿易について次のように言及されていた。

・国境貿易とは，国境地域の常住民と隣国の国境地域の常住民の間に括いて，ロシア政府と 隣国政府の協定によって定められた国境地域で, 国境地域にとっての必要品拉よび消費財 についてなされる貿易である。

・国境貿易の制度と国境貿易地域については, ロシア政府と隣国政府の協定に基づいてロシ ア政府が定める。

この二つの法令から， ロシア政府が国境貿易を認めていることは分かるが，筆者の知る限 り，具体的な政策は作られなかったよらである。

アレクサンドロフの先行研究 (Александрова, 2005) から分かるように， ロシアの国境貿易 は, 㛜密な定義があるのではなく, 単にロシア国境地方と隣接する国の間の貿易と考えられ る。そらではあるが，中口国境貿易がロシア国境地域にとって大きな役割を果たしているのは 事実である。たとえば，2006年に，アムール州の対中国貿易は，同州対外貿易の $84.9 \%$ を占 め, 同様にハバロフスク地方では $46.9 \%$, 沿海地方では $38.9 \%$ を占めた（『ロシア東欧貿易調 査月報』第 9-10 号, 2006 年, 71-73 ページ)。

国境貿易を直接的に規制するものではないが，間接的に国境貿易に影響を与えているのは， 次のような担ぎ屋貿易に関わるものである。ロシア政府は，担ぎ屋貿易を制限するため，ロシ アに入国する際の個人携帯品の重さおよび金額に関して次のような政策を取ってきた。

（1）1993 年 12 月 23 日付ロシア政府決定第 1322 号により，1994 年 4 月 1 日からロシアに入国 する際，個人携帯品として 2000 ドルまでの商品は免税とされ，2000ドルから 1 万ドルまでの 商品については 60\% の関税が徵収される (Собрание актов Президента и Провительства РФ, 1993, No. 52, стр. 5089)。

（2）1996年 7 月 18 日付ロシア政府決定第 808 号により，1996 年 8 月 1 日からロシアに入国す る際, 個人携帯品として 1000 ドル以内, あるいは重さが $50 \mathrm{~kg}$ 以下の商品は免税とされ，1000 ドルから 1 万ドルまで, あるいは重さが $200 \mathrm{~kg}$ 以内の商品は $30 \%$ の関税, あるいは $1 \mathrm{~kg}$ 当た り少なくとも 4 ユーロが徵収される（Собрание законодательства РФ, 1996, №. 30, стр. 3660)。

（3） 2003 年 11 月 29 日ロシア政府決定第 718 号により，2004 年 1 月 1 日からロシアに入国す る際，個人携帯品として 6 万 5000 ルーブルまで，あるいは $50 \mathrm{~kg}$ までの商品は免税とされる。 6 万 5000 ルーブルから 65 万ルーブルまで，あるいは $50 \mathrm{~kg}$ から $200 \mathrm{~kg}$ までの商品は $30 \%$ の 関税，あるいは $1 \mathrm{~kg}$ 当たり少なくとも 4 ユーロが徵収される。な敃出入国は週 1 回に限定さ れた (Собрание законодательства РФ, 2003, №. 49, стр. 4772)。

（4） 2006 年 1 月 26 日付ロシア政府決定第 29 号により，2006 年 2 月 25 日からロシアに入国す 
る際，個人携帯品の重さは以前の週 1 回 $50 \mathrm{~kg}$ から月 1 回 $35 \mathrm{~kg}$ に制限された (Собрание законодательства РФ, 2006, No. 5, стр. 550)。

この四つの政策の変化については，次のようにまとめられる。

政策（1）では，個人携帯品の金額が制限されたが (2000ドルまで)，重さは制限されなかった。 政策（2）では，個人携帯品の金額がさらに制限され（1000ドルをで），重さも制限されるよ らになった（50 kg まで）。政策（3）では，個人携帯品の金額が，以前より引き上げられた（6 万 5000 ルーブルまで）(2)。政策（4）では，個人携帯品の重さ（35 kg ‡で）と出入国の頻度（月 1 回）が厳しく制限された。

これらの政策は，担ぎ屋貿易に大きな影響を与えた。たとえば，綏芬河の対ロシア担ぎ屋貿 易が 2005 年の 7 億 9000 万ドルから 2006 年の 5 億 1000 万ドルに減少したのは（後述の表 2 参 照)，(4）の政策の影響によるところが大きいと見られる。

\section{3 黒龍江省の対ロシア国境小額貿易}

中国の国境貿易が中国の対外貿易全体のなかで占める比重は小さいが，中口貿易において は，国境貿易は大きな比重を占めている。たとえば，2006年に，中国の国境小額貿易額は 161.6 億ドルで，対外貿易総額の $0.9 \%$ を占めたが，中ロ国境小額貿易額は，対ロシア貿易総 額の $21.0 \%$ を占めた ${ }^{(3)}$ 。また，黒龍江省の対ロシア国境小額貿易額は同省の対ロシア対外貿 易の $69.4 \%$ を占めた。中口国境貿易は国境地域の経済発展にとって大きな意味を持っている。

中ロ国境貿易地域は，中国側では吉林省，黒龍江省，内モンゴル自治区，新疆ウイグル自治 区と，ロシア側では沿海地方，八バロフスク地方，ユダヤ自治区，アムール州，チタ州，アル タイ地方である。

中ロ国境は $4300 \mathrm{~km}$ あり，そのなかで黒龍江省とロシアの国境は $3045 \mathrm{~km}$ ，中ロ国境の $70 \%$ を占めているので, 中ロ国境貿易の大部分は黒龍江省とロシア極東の隣接地域の間で行われて いる。図から分かるように，近年，黒龍江省の対ロシア国境小額貿易は中国の対ロシア国境小 額貿易の 6 割以上を占めている。黒龍江省の対ロシア国境小額貿易の変動は，中ロ国境小額貿 易全体の变動を規定している。

1982 年 4 月 16 日，中国政府とソ連政府は「貨物交換及び支払い議定書」を締結した。これ によって中ソ国境貿易は回復した（『中国対外経済貿易年鑑』1985，p. 169）。黒龍江省の対ソ 連国境貿易の回復は 1983 年からである。1983 年に，黒龍江省の綏芬河と黒河は対ソ連開放陸 上貿易港となった（『中国対外経済貿易年鑑』1984，p. 76）。ソ連側も，ハバロフスク地方，沿 海地方，アムール州，チタ州に拈いて，「全ソ極東対外貿易連合会社」を通じて黒龍江省及び 内モンゴル自治区との貿易を開始した。1 章に記した 1984 年の「国境小額貿易に関する臨時 管理弁法」によって，国境対外貿易会社は直接ソ連との貿易に従事できるようになった。ま た，1988 年に，黒龍江省は対ソ連国境経済管理局を設立し，対ソ連貿易の管理と指導，契約， 価格などの調整を行うとした。中央政府と地方政府の一連の政策の結果として，黒龍江省の対 ソ連国境貿易は 1984 年の 2800 万スイスフラン（約 1100 万）ドルから 1989 年の 5 億 7000 万

(2) 6 万 5000 ルーブルは，当時のレートで 2200 ドルに相当する。この時期に免税額が引き上げられた理 由については，今後検討する。

(3) 1 節に記したように，国境貿易については，国境小額貿易のみの統計が取られている。 


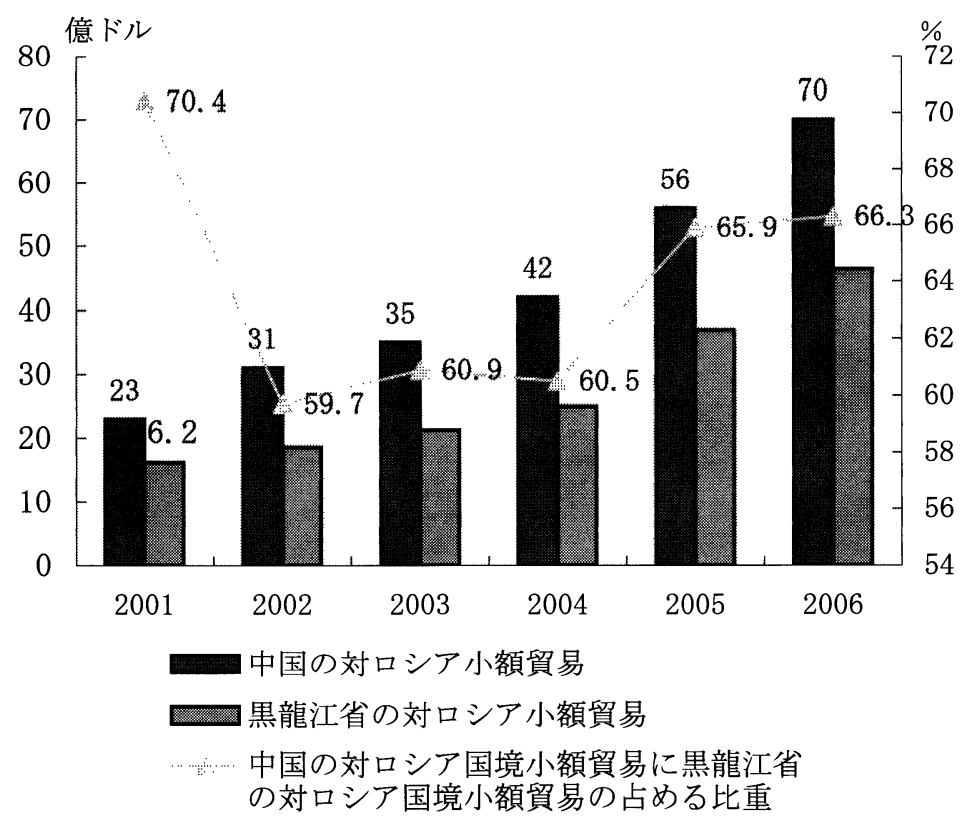

図中ロ国境小額貿易と黒龍江省の対ロシア国境小額貿易

スイスフラン（約 2 億 5000 万ドル）に増加した（『中国対外経済貿易年鑑』1985 年，169ページ， 1990 年, 186 ページ)。

ソ連崩壊後，ソ連を継承したロシアとの間で国境貿易はいっそら発展した。中国全体につい ては 1990 年代の時系列データが得られないが，黒龍江省については，そのようなデータが得 られるので，表 1 によとめた。同表のデータにより，黒龍江省の対ロシア国境小額貿易の発展 については，1991 年以降，大きく次の三つの時期に分けられる (4)。急成長期（1991-1993 年), 低迷期（1994-1999 年），2000 年以降の安定成長期である。

\section{（1）急成長期（1991-1993 年）}

1991 年にロシアが独立した直後，黒龍江省の対ロシア国境小額貿易は急速に発展した。同 貿易額は，1991 年の 8 億 7000 万ドルから 1993 年の 20 億 9000 万ドルに達し， 3 年間で 2.5 倍 に増加した。貿易急増の要因としては次のことが考兄られる。

（1）1990 年に入ってから中央政府と地方政府は国境地域の経済を発展させるために，いっそう 力を入れた。たとえば，ソ連・東欧諸国との経済・貿易を発展させるため，1990年から年 1 回 のソ連・東欧諸国向けの経済・貿易見本市がハルビン市で開かれた ${ }^{(5)}$ 。1991 年 4 月， 1 節で説

(4) 表 1 では，1995 年以前と 1996 年以降では出所（定義）が異なっており，そのことが同表の数值にど の程度の影響を与えているかについては今後の検討課題としたい。

(5) 中国ハルビン国際経済・貿易見本市は三つの時期に分けられる。すなわち，(1) 1990-1991 年の対ソ連 ・東欧諸国経済貿易見本市の時期で，当時は洼とんぞがバーター貿易であった。（2）1992-1995 年の中 国ハルビン国境地域経済・貿易見本市の時期。参加国は主にロシアなど CIS 諸国及び東欧諸国で, 1994 年から日本，韓国なども参加した。（3）1996年以降, 中国ハルビン国際経済・貿易見本市と改称 された時期。世界向け，とくに，ロシア向けの見本市である。この見本市は黒龍江省の経済・貿易に 大きな役割を果たしている。以上は, http://www.00615.net/wshqh/html/hqh/1-huigu/2-jieduan/2_jd_1. php（中国ハルビン国際経済・貿易見本市のサイト）による。 
表 1 黒龍江省の対ロシア国境小額貿易の推移（単位 : 億ドル）

\begin{tabular}{|l|c|c|c|}
\hline & 黑龍江省の対ロシア貿易額 & 黒龍江省の対ロシア国境小額貿易額 & 国境小額貿易の比率 $(\%)$ \\
\hline 1990 & $5.8(7.2)$ & & \\
\hline 1991 & $8.7(10.6)$ & & \\
\hline 1992 & $15.9(20.7)$ & & \\
\hline 1993 & 20.9 & & \\
\hline 1994 & 16.3 & & \\
\hline 1995 & 14.6 & 7.0 & 62.5 \\
\hline 1996 & 11.2 & 6.9 & 69.0 \\
\hline 1997 & 10.0 & 6.1 & 89.7 \\
\hline 1998 & 6.8 & 7.7 & 84.6 \\
\hline 1999 & 9.1 & 10.1 & 74.2 \\
\hline 2000 & 13.6 & 10.9 & 61.2 \\
\hline 2001 & 17.8 & 18.5 & 79.3 \\
\hline 2002 & 23.3 & 21.3 & 72.4 \\
\hline 2003 & 29.4 & 25.4 & 66.5 \\
\hline 2004 & 38.2 & 36.9 & 64.9 \\
\hline 2005 & 56.8 & 46.4 & \\
\hline 2006 & 66.9 & & \\
\hline 199 & & & \\
\hline
\end{tabular}

（注）11 1995 年以前の黒龍江省の対ロシア貿易額は, 同省の対ロシア国境地方バータ一貿易額である。 1996 年以降の対ロシア国境小額貿易は，国境市・県所在企業の対ロシア貿易額である。

(2) 1992 年以前の中国の対ロシア貿易についてはスイスフラン建てで統計が取られた（括弧内の数 字)。そこで，当時の為替レート（『中国統計年鑑』，2003，p.654）によってドルに換算した。

（出所）1990-1998 年のデータ：中国対外経済貿易年鑑（1991-1999）。

1999-2005 年のデータ：黑龍江省統計年鑑（1999-2005）。

2006 年のデータ : http://www.customs.gov.cn/YWStaticPage/1731/85843eb7.htm（ハルビン海関のサ イト)。

明した「国境貿易と国境経済協力を積極的に発展させ，国境の繁栄安定を促進することに関す る意見の通知」が出され，輸入関税と輸入付加価値税が半額とされた。この政策は，国境貿易 を促進する大きなインセンティヴとなった。また，1992年 3 月，中央政府は黒河市，綏芬河 市 (以上, 黒龍江省), 満州里 (内モンゴル), 琿春（吉林省）を国境経済開放都市に指定した (『中国対外経済貿易年鑑』1993，p. 322)。これにより，黒龍江省政府は黒河市，綏芬河市に多 くの優遇政策を与えた ${ }^{(6)}$ 。1991 年から，黒龍江省政府は対ソ連国境貿易の拡大を外向型経済 発展の重点とすることを決めた（陸，1999，p. 168）。国境地域を全面開放し，通関ポイントの

(6)（1）両市に所属する国境貿易会社が輸入する肥料は，尿素を除いて，全てその他の省・自治区に販売 することができる。

（2）両市にロシアへの工事請負（100万ドル以下）, 労務輸出（100人以内）についての審査, 認可権 を与える。

（3）国が割当，許可証管理を実行すると規定したバータ一貿易輸出入商品について，一括で取扱い総 数を決め, その枠内で両市が実行する（『商務政策選編』2006, p. 67) 
増設, 施設の整備, 道路などのインフラ建設に力を入れるとともに, 国境貿易参入基準を緩和 した。その結果，多くの企業が国境貿易に新規に参入した。

（2）ソ連が崩壊したばかりで，口シアにおいて食料品及び消費物資の深刻な不足が生じた。国 民の購買力が低下する中で，中国の安価な商品はロシア市場で比較優位性を持っていた。

（3）1991 年にロシアは輸出入に関する規制を暖和し，すべての企業が輸出入業務に従事できる ようになった。そのため, 国境貿易に従事する会社が急増した。1992 年 12 月に中口観光団体 の査証相互免除の協定が結ばれた。これに伴い，中口両国民の商務往来が容易になり，個人が 商品を携帯し，国境を行き来して販売するいわゆる担ぎ屋貿易が盛んになった。

（4）80年代から 1993 年にかけて中ソ（口）貿易はほとんどバータ一方式で行われていたので, 外貨がなくても，貿易を行らことができた。

\section{（2）低迷期（1994-1999 年)}

1994 年から 1999 年むで, 黒龍江省の対ロシア国境小額貿易は减少した。貿易額は 1994 年 の 16 億 3000 万ドルから 1998 年の 6 億 1000 万ドルに減少した ${ }^{(7)}$ 。中国側の原因としては次 の諸点が考えられる。

（1）1980 年末から 1990 年初頭にかけての中口国境貿易の自由化は, 無秩序と混乱を招き, 詐 欺行為と劣悪商品の横行が国境貿易の発展に悪影響を与えた。

（2）中国は1993 年の後半期から経済の引き締め調整を実施し，建設需要が大幅に減少し，口 シアから鉄鋼と機械・設備の輸入が激減した。

（3）1994 年から中国政府は国境貿易について肥料，鉄鋼などの商品に割当許可制を導入した。 この政策は国境貿易の発展を妨げた。

ロシア側の要因としては次の諸点が考号れる。

（1）インフレに伴い輸出価格が高騰した。

（2）輸入関税の引き上げと許可制度の厳格化などの措置が取られ, 中ロ間のバータ一貿易に制 限が加えられた。当時, 中国とロシアは外貨準備が不足していたので, バータ一方式ではな く, 貿易決済をすべて外貨で行うのは不可能であった。そのため, 中口国境貿易が大きく制約 された。

（3）ロシアの経済の長期不況によって，企業の経営状況が悪化し，契約の不履行が多くなり， それに伴らトラブルの多発も国境貿易に悪影響を及ぼした。

（4）担ぎ屋貿易の活動に秩序をもたらす目的で査証制度が再導入され，查証発行数が制限され たことも，人的往来などに大きな影響を与えたと考えられる。

（5）1998 年のロシア金融危機とそれに伴らルーブルの大幅切り下げは, 中ロ国境貿易にも影響 した。

\section{（3）安定成長期（2000 年以降）}

中央政府と地方政府は共に上記の低迷期に明らかになった諸問題を重視し，対策を採った。 黒龍江省国境貿易管理局は国境貿易に従事するすべての会社の資格を再審査し，多くの実力不 足の会社の資格を取り消した。また，品質劣悪商品の流出を防ぐため，税関品質検査制度を強

\footnotetext{
(7) 表 1 において, 1994 年と 1998 年のデータでは定義が異なることについては, 同表の注(1)参照。
} 
化した。

2000 年からロシア経済が好調に発展しており, 両国の外貨準備の増加に伴って, 中口貿易 の決算はすべて外貨で可能になった ${ }^{(8)}$ 。これらの要因により，中口国境小額貿易額は 2000 年 の 10 億 1000 万万ドルから 2006 年の 46 億 4000 万ドルに増加した。

国境貿易の商品構成については，中国対外経済貿易年鑑によると，90 年代初め頃，中国の 対ロシア輸出商品は主に食料品，衣類などが大きな比重を占めていた。近年は，衣類は依然と して主要輸出商品であるが, 電気製品, 機械・設備の輸出が急増して, 主要輸出商品になって いる。つまり，中国の対ロシア輸出商品は低品質の商品から良質になりつつあり，低付加価值 商品から高付加価值商品の取引に变化しつつある。ロシアからの輸入商品は, 90 年代初め頃 は，主に肥料，木材，機械・設備，車などであったが，近年，木材，鉄鋼などの原材料に集中 する傾向が目立っている。

貿易の主体については，80 年代から90 年代初めにかけては，国境小額に従事する貿易主体 のほとんどが国営企業であったが，90 年代半ば以降，私営企業が中心となった。2006 年に, 私営企業の対ロシア国境貿易額は黒龍江省の対ロシア国境貿易額の $83.6 \%$ を占めた（ハルビ ン海関統計)。

また，近年の大きな変化として，通過型貿易から加工型貿易への転換を上げることができ る。1980 年代には, 国境地域からロシアに輸出する商品のなかで地元産のものは非常に少な く，広東，上海などをはじめとする東南沿海地域から消費財が調達され，国境通関ポイントを 通じてロシアに輸出されていた。一方，ロシアから輸入した木材，肥料などは加工することが なく，そのまま南部地域に販売されていた。

近年は，ロシアへの輸出商品とロシアからの輸入商品ともに現地での加工が増えている。国 境地域の都市には様々な加工園区が建てられた。たとえば, 綏芬河には輸入加工園区と輸出加 工園区が建てられ，輸入加工園区では主に木材加工が行われている。綏芬河の対ロシア木材輸 入は中国の対ロシア木材輸入の約 3 割, 黒龍江省の対ロシア木材輸入の 7 割を占めている。 2006 年に綏芬河木材加工園区の木材加工企業は 410 社, その加工能力は年間 450 万 $\mathrm{m}^{3}$ であっ た。同年に，綏芬河の木材輸入は 664 万 $\mathrm{m}^{3}$ であり，そのうち約 7 割が現地で加工された。綏 芬河の輸出加工園区には衣服加工園区, 靴加工園区, 機械加工園区, 電気加工園区などがあ る。現在, 綏芬河のロシア輸出商品の多くは現地で生産されたものである。

中口国境貿易の発展は，国境地域の地方収入の増加だけではなく，国境地域のインフラの整 備を推し進め, 国境地域の経済構造の变化をも促進している。たとえば, 2006 年に, 綏芬河, 東寧市の財政収入の 8 割は対ロシア貿易から徵収されたものであった（『黒龍江経済報』2007 年 2 月 26 日 p. 7)。以前は，綏芬河，東寧市などの国境都市では，第 1 次産業である農業が経 済のなかで圧倒的な位置を占めていたが，国境貿易の発展により，商業，サービス業などを中 心とした第 3 産業が急速に成長している。

\section{4 旅行買い物貿易（倒包貿易）}

中口国境貿易に打ける特殊な貿易形態は旅行買い物貿易である。旅行買い物貿易とは旅行の

(8) 実際には，両国通貨の外貨との交換可能性が高まったことにより，2005年 1 月 1 日から中口国境貿易 に打いてルーブルと人民元により決算がなされるよ5になった（『黒龍江経済報』2005 年1月5日p. 7)。 
方式で遂行する商務活動である。中口間の旅行買い物貿易は, ソ連崩壊後, 生をれたものであ る。2001 年から黒龍江省はこの貿易を海関統計に記録し始めた。このような統計が得られる のは, 筆者の知る限り, 黒龍江省のみである。この貿易方式は委託輸出と担ぎ屋輸出の 2 種類 に分けられている（綏芬河商務局に㧍ける筆者の聞き取り調査による）。中口間の旅行買い物 貿易は, 単一方向の貿易である。つまり中国の対ロシア輸出であり, 対ロシア輸入は存在しな い。

\section{(1) 委託輸出}

委託輸出は, 中国で購入した商品を自分で持ち帰るのではなく, 代理通関会社に委託して運 送するものである。このような貿易は，いわゆる灰色通関貿易である。ここでは，2007年 7 月に中ロ国境の綏芬河で行った調査に基づき，この貿易の流れを紹介する。

中国あるいはロシアの商人は購入した商品を中国代理通関会社（发包公司）に委託してロシ アに輸出する ${ }^{(9)}$ 。中国代理通関会社は中国側で通常の通関申告などの手続きをして，ロシア 側の代理通関会社に商品を搬送する ${ }^{(10)}$ 。ロシア側の代理通関会社とロシア通関は特殊な関係 にあるので，輸出した貨物はロシア通関で早く，安く手続きできる。具体的な費用は次の通り である。

綏芬河（口岸）の委託輸出は, 道路通関ポイントを通じて, 大型トラックで運送する。一般 的に, 一つのトラックの積載貨物はロシア代理通関会社の要求によって 44 トン以下である (2007 年 7 月 26 日, 綏芬河市の代理通関会社に拉ける聞き取り調査)。中国代理通関会社が梱 包する貨物の一つの包の大きさは $1 \mathrm{~m}^{3}$ ある。1 台のトラックには 140 の包が載せられる。一 つの包ごとに中国輸出代理通関会社に 500 ドルが支払われる。したがって，1台のトラックの 費用は 7 万ドルである。中国代理通関会社は，そのなかからロシア側代理通関会社に 1 台のト ラックの通関費用として 5 万ドルを支払う。黒龍江省の中国海関では, この貿易方式で輸出し た貨物が国境小額貿易として記録される。

\section{（2）担ぎ屋貿易（綏芬河）}

現在, 中国側の中ロ国境都市に毎日買い物に来るロシア人は少なくない。彼らは購入した商 品を自分で持ち帰る。黒龍江省とロシアの国境通関ポイントでは, 手荷物が $50 \mathrm{~kg}$ 以下の場合, 自由に持ち帰ることができる。 $50 \mathrm{~kg}$ 以上の場合, 超える部分について $1 \mathrm{~kg}$ 当たり 10 元（約 1.3 ドル）の税金が徵収される。これは黒龍江省が定めた政策であると思われる。政府によって指 定された会社がこの税金を徵収し, 商品分類を行い, 通関に報告する。2001 年以降, 通関がこ の貿易方式で貿易額を記録し, 通関統計に記入している。表 2 は, 綏芬河の通関統計（今回の 調査により入手）に基づくものである。同表の「その他」のほとんどすべてが担ぎ屋貿易であ る（2007 年 7 月 25-27 日の綏芬河海関における筆者の聞き取り調査による）。それによると， 「その他」は近年急速に増えて打り，2005 年には 7.9 億ドルに達している ${ }^{(11)} 。$

（9）綏芬河には代理通関会社が多く，とくに，億亨，龍江商連，林源をはじめとする6社が有名である。

(10) ロシア極東地域に拈ける最も大きな代理通関会社はアリヤス（Ariyas）である。地元では, この会社 の裏の支配人は元沿海州知事であると言ら噂がある（筆者の聞き取り調査による）。

（11）「その他」の 2001 年以降の急速な増加は, 担ぎ屋貿易の増加自体を示すだけでなく, 担ぎ屋貿易のよ り大きな部分が通関にきちんと報告されるようになったことを示すように思われる。 
表 2 綏芬河の対ロシア貿易（単位 : 億ドル）

\begin{tabular}{|c|c|c|c|c|}
\hline & 総額 & 一般貿易 & 国境小額貿易 & その他 \\
\hline 2001 & 12.4 & 0.8 & 11.4 & 0.2 \\
\hline 2002 & 15.3 & 0.8 & 13.0 & 1.5 \\
\hline 2003 & 18.4 & 2.3 & 13.6 & 2.5 \\
\hline 2004 & 21.5 & 3.9 & 14.2 & 3.4 \\
\hline 2005 & 25.4 & 2.2 & 15.3 & 7.9 \\
\hline 2006 & 25.5 & 5.0 & 15.4 & 5.1 \\
\hline
\end{tabular}

（出所）綏芬河海関統計

\section{（3）担ぎ屋貿易（ウスリースク）}

現在でも， ロシアで小売に従事する中国人は少なくないが，具体的な人数，年間の売り上げ については不明である。筆者は 2007 年 8 月 23-25 日に, ウスリースクの「中国市場」で小売 に従事する中国人（6人）に聞き取り調査を行った。それに基づいてロシアにおける担ぎ屋の 状況を紹介したい。

ウスリースク市で最も大きな市場は「中国大市場」である。その中には 1500 の店舗がある。 2007 年以前は，この市場で中国人は約 1000 の店舗を持っていた。店主に対する聞き取りによ ると，2006 年以前は，一つの店舗は，平均的に，年間 3-4万ドルの純利潤を得ていた。2007 年 1 月から，ロシア政府は, 外国人が露天市場で小売に従事することを禁止したので ${ }^{(12)}$, 現 在この市場で小売に従事する中国人は少なくなり，200人ぐらいとなっている。現在 , 中国人 商人は自ら販売するのではなく，ロシア人を雇って販売している。雇ったロシア人の給料は, 1 日 500 ルーブル，1月で 1 万 5000 ルーブルである。

\section{5 中口国境貿易の問題点}

近年，中口国境貿易は近年大きく発展しているが，様々な問題も存在している。

（1）中国側の国境貿易政策の弱体化

国境小額貿易の輸入関税と輸入付加価值税を半額とする政策は，WTO の規定に違反するた め，中国の WTO 加盟 5 年経過以降，すなわち，2006年 11 月以降，段階的に縮小されている。 2006 年には，約 200 種類の輸入商品についてこの政策が適用されなくなった。しかし，こう した政策は，国境貿易の発展にとって非常に重要なので，中央政府と地方政府にとって何らか の措置を講じることが喫緊の課題となっている。

（2）中国側の許可証制と割当管理制

国境小額貿易の規定によって，国境小額貿易に従事する企業は，隣国から制限の対象である

(12) 2006 年 11 月 15 日付ロシア政府決定第 683 号により，2007 年 1 月 15 日以降，外国人がロシアにおい て酒類（ビールを含む），医薬類の小売業に従事することが禁止された。また，2007 年 1 月 15 日から 3 月 31 日まで露天市場で小売業に従事する外国人は経営主体で雇用されている総従業人数の $40 \%$ に 制限され，2007 年 4 月 1 日から 12 月 31 日までこの割合を $0 \%$ に制限された。つまり，2007年 4 月 1 日外国人は露天市場で小売に従事することが禁止された（Российская газета, 2006.11.16, №. 257, стр. 16)。 
商品, あるいは割当の対象である商品を輸入する際，毎年商務部から輸入許可証，あるいは割 当を取得することが必要である。しかし，輸入許可証，輸入割当額がもらえない，あるいはそ れが遅れるなどの原因で貿易に従事できないことがしばしばある。また，ロシアとの貿易に従 事する際，ロシア側に商品の代金を支払う能力がなく，実物で返済することがしばしばある。 しかし，この実物が許可証を必要とする商品，あるいは割当の対象である商品のため, 中国側 が最後になって取引を放棄する例が見られた。

（3）ロシア側の通関の問題

ロシア政府は国内産業, 特に国内の弱い産業を保護するために, 輸入商品に対する輸入関 税, 輸入制限, 輸入許可などの貿易障壁を設ける場合がある。さらに, 問題なのは, 税関職員 が極めて怨意的にこうした制度を運用することである。たとえば， ロシアの輸入関税には従量 税と従価税を組み合わせた混合税があるが，税関は関税を徵収する際，関税の高い方式によっ て徵収する傾向がある。皮革製品（ロシアの貿易品目分類 HS43）の輸入関税は, 従量税によ る関税が，従価税による関税を著しく上回っていると言われ，従量税によって徵収されるケー スが多い（张，2003， p. 79）。繊維・繊維製品, 皮革製品, 靴などは国境貿易の主要輸出商品 であるが，ロシアの税関職員の裁量の余地が大きく，そのことが灰色貿易の存在する要因の 1 つになっている。

（4）ロシア側の資源輸出の制限

木材はロシアからの輸入重要商品の一つである。ロシアから輸入される木材は主に原木であ り，中国木材輸入の 5 割を占める。ロシアからの木材輸入は主に国境小額貿易で取引された。 近年, ロシア政府は資源輸出を制限するため, 様々な政策を出している。2007 年 2 月 5 日付 ロシア政府決定第 75 号により，木材（原木）の輸出関税は 2007 年 7 月 1 日以降，契約金額の $20 \%$ ，あるいは少なくとも $1 \mathrm{~m}^{3}$ 当たり 10 ユーロ，2008 年 4 月 1 日以降，同じく $20 \%$, ある いは15ユーロ，2009年1月 1 日から同じく40\%，あるいは40ユーロと定められた (Собраниез аконодательства РФ, 2007, №. 7, стр. 896)。この政策が実行されると, ロシア原木輸出は不可 能になると考えられる。中国側では, 既述のように, 綏芬河などに木材加工区が設けられてお り，原木での輸出がなくなると，大きな影響が出てくると予想される。

\section{終わりに}

本稿では国境貿易の定義や政策を明らかにし，1990 年代から 2006 年まで 10 数年間の黒龍 江省の対ロシア国境貿易の変動とその要因について検討した。その結果, 国境貿易の変動に は，両国政府の政策（中国の地方政府の政策を含む）が大きな影響を与えていること，近年は 両国経済の高度成長が国境貿易の拡大に大きく寄与していることが明らかにされた。

中口国境貿易においては上述の諸問題が存在しているが，現在の中口政治・経済関係は基本 的には中口国境貿易の安定的な発展を保障するものとなっていると考えられる。さらに，ロシ アのWTO 加盟が実現することにより, 貿易の秩序が整えられ, 輸入関税が引き下げられるな らば，中ロ国境貿易はさらに発展していく可能性がある。 
刘志强主编『中越边境贸易研究」民族出版社, 2006 年。

刘秀玲等编『著边境贸易与民族地区生态环境发展论』民族出版社, 2006 年, 民族出版社。

刘兴光・王新力・金有德主编『中俄经贸指南」中国标准出版社, 2006 年。

薛君度・陆南泉主编『中俄经贸关系』中国社会科学出版社 1999 年。

『黑龙江统计年鉴』黒竜江社会科学院出版, 2000-2006 年。

『中国対外经济贸易统计年鉴』中国対外贸易出版社, 1984-2000 年。

Александрова, М. В. Российско-китайские приграничные экономические отношения.

Москва. ОГНИ.2005г.

Нырова, Н. Н. китайские компании приграничной торговли и их место в международной преступной деятельности//проблемы ДВ.No.4.2004г.

田畑伸一郎「ロシア統計システムに拈ける貿易の問題」『経済研究』第 50 巻第 4 号, 1999 年。 『ロシア東欧貿易調査月報』第 9-10 号，2006 年。 